\title{
Geotechnical and Geochemical Assessment of Natural Sands in Ahanta West Area, Southwestern Ghana
}

\author{
Asante-Annor Asare, Kwabena Amponsah Ernest \\ Geological Engineering Department, University of Mines and Technology, Tarkwa, Ghana \\ Email: aasante-annor@umat.edu.gh
}

How to cite this paper: Asare, A.-A., \& Ernest, K. A. (2021). Geotechnical and Geochemical Assessment of Natural Sands in Ahanta West Area, Southwestern Ghana. Journal of Geoscience and Environment Protection, 9, 265-285.

https://doi.org/10.4236/gep.2021.912016

Received: November19, 2021

Accepted: December 28, 2021

Published: December 31, 2021

Copyright $\odot 2021$ by author(s) and Scientific Research Publishing Inc. This work is licensed under the Creative Commons Attribution International License (CC BY 4.0).

http://creativecommons.org/licenses/by/4.0/

(c) (i) Open Access

\begin{abstract}
Geotechnical and geochemical assessment of natural sands being used as fine aggregates for construction purposes in Ahanta West and its Environs was carried out, as well as addressing the environmental problems associated with the exploitation of these sand through the sand winning activities. The results from geotechnical and geochemical tests were bench marked with British, American and Ottawa Standards for testing materials. Representative samples were taken from five different sand winning sites namely, Pompuni, Agona Banso, Fretsi, Tumentu stream and Fretsi river. The geotechnical tests carried out were specific gravity, grain size analysis, moisture content, silt content, permeability test using the constant head permeameter method. The photometer (Hydro Test HT 1000) was used to determine silica, sulphate and chloride concentrations in the sand samples. The oxides for the geochemical analysis were determined using the X-ray fluorescence (XRF) method. The results from the study areas showed that except for Fretsi, the specific gravity, grain size analysis, moisture content, silt content and permeability tests were within the acceptable range for natural sands. Sand samples from Pumponi and Agona Banso had the required $\mathrm{Cu}$ and $\mathrm{Cc}$ values of being well graded. Sulphate and chloride concentrations were within standards for all the samples; however, silica was low for all the samples. $\mathrm{Fe}_{2} \mathrm{O}_{3}, \mathrm{Al}_{2} \mathrm{O}_{3}, \mathrm{MnO}$ and $\mathrm{Na}_{2} \mathrm{O}$ did not meet the Ottawa sand standard. Natural sand is not recommended to be used for construction purposes however, these sands may be treated or blended if it is to be used for construction purposes. There are serious environmental implications for the sand-winning activities in the study areas such as stripped overburden, creation of pits and ponds, increased total suspended solids in surface waters, and destruction of aquatic habitats which needs to be addressed.
\end{abstract}




\section{Keywords}

Geotechnical Assessment, Geochemical Tests, Natural Sand, Construction, Ahanta West

\section{Introduction}

Sand winning refers to the scooping of sand from portions of the earth's surface for building construction and other developmental purposes (Peprah, 2013). Mattamana et al. (2013) state that sand mining has become an industry giving job opportunities for thousands of people. In the Ahanta West district of Ghana, sand wining gives employment to some of the youth. Mining of natural aggregates such as sand serves as the main source of construction aggregate used throughout the world (Musah, 2009).

ASTM C125-03 (ASTM, 2003) defines fine aggregate (sand) based on the particle size as an aggregate passing the $9.5 \mathrm{~mm}$ (3/8in.) sieve and almost entirely passing the $4.75 \mathrm{~mm}$ (No. 4) sieve and predominantly retained on the $75 \mu \mathrm{m}$ (No. 200) sieve. According to the environment of deposition, natural sand can be classified as "pit, river or sea sand" based on its natural sources (Gopi, 2009). Tetsopgang et al. (2020) classified pit sand as the residual soil deposits formed from an in situ weathering of granular rocks such as granites. The open pits start at $0.2-2 \mathrm{~m}$ depth, however depending on the location can be up to a depth of about $100 \mathrm{~m}$. These sand deposits from the soil consist of sharp angular grains which serve as an excellent material for mortar or concrete works (Tetsopgang et al., 2020).

Different types of sand have specific properties and are used in different industries, construction, glass manufacturing, foundry industry, metal production, chemical production, ceramics and refractories, paint and coatings, filtration and water production, oil and gas recovery and recreational products (Anon, 2017). Some of the important aspects of sand include strengthening buildings when mixed with cement and concrete, plastering, mixing with concrete when making foundations, and moulding bricks for building of homes and rental houses that bring income to villagers (Madyise, 2013).

Aggregates are the major constituents of concrete, typically occupying between $70 \%$ and $80 \%$ of its volume. Therefore, it is expected that aggregates have an important influence on the concrete parameters (Thomas and Folliard, 2007). Mineralogical composition of the aggregates, and more specifically their alteration degree, strongly influence their mechanical behaviour and their in-service performance (Petrounias et al., 2018; Petrounias et al., 2016). Mehta \& Monteiro (2001) stated that aggregates exercise a significant influence on strength, dimensional stability, and durability of concrete. In addition to these important properties of hardened concrete, aggregates also affect greatly the cost and workability of concrete mixtures. Chen \& Liu (2004) as well as Rao \& Prasad (2002) con- 
sidered aggregates as the skeleton of concrete and consequently persuaded that all forms of coatings should be avoided to achieve good concrete.

Literature research indicates that the major causes of buildings failure are dependent on the quality of building materials used (sand, coarse aggregates, steel reinforcement, water), workmanship employed in the concrete mix proportioning and construction methodology, defective designs and non-compliance with specifications or standards (Machuki, 2012; Oloyede et al., 2010; Tetsopgang et al., 2020).

Cases of structural failures have been recorded around the world in cases such as the Ranza Plaza in Bangladesh, Sampoong Departmental Store in South Korea, Royal Plaza Hotel in Thailand, the Highland Towers in Malaysia and the Versailles Wedding Hall in Jerusalem. Similarly, some structural failures recorded in Ghana include the Achimota Melcom and the Nii Boi Town hotel collapse (Ansah, 2014). Among the many reasons for the collapse, the quality of sand aggregates cannot be completely ruled out. In Ghana, other researchers have worked on sand and gravel mining (Peprah, 2013; Jonah et al., 2015; Narh, 2016; Baba, 2017). Most of these works focused on the positive and negative impacts of sand winning. Some of the negative impacts reported include environmental degradation, water pollution, destruction of the soil structure, facilitating soil erosion with abandoned pits acting as breeding grounds for water-induced diseases and death-traps (Jonah et al., 2015; Narh, 2016; Baba, 2017). Other studies, such as Narh (2016) and Aromolaran (2012) revealed the occurrence of similar activities in the Dormaa District in the Brong Ahafo Region and Ogun State in Nigeria respectively. Mireku-Gyimah \& Tsidzi (1996), studied sand and gravel mining in southern Ghana and designed appropriate mining systems to offset degradation. In Nigeria, Ajagbe et al. (2017) investigated fine aggregates from different sources in Ibadan and its environs for concrete production whilst Abdullahi (2006), studied the properties of some natural fine aggregates in Minna. Ojuri \& Fijabia (2012) established reference standard sand in Nigeria for engineering and geoenvironmental purposes. The properties of the samples were compared with a standard Ottawa sand in Illinois of the United States.

Ottawa sand comes from the historic deposits located at Ottawa, Illinois and mined from the St. Peter formation. These $\alpha$-quartz sand deposits have been mined for well over 100 years and are used in many areas besides cement and concrete (Erdoğan et al., 2017). The sand also serves as a specification for graded sand, 20/30 sand, as well as masonry cement and is often used as a standard for chemical analysis of natural sand. The Ottawa sand was chosen by the American Society for Testing and Materials (ASTM) as the standard sand to be used in testing cement and the strength of concrete. Because the sand is typically regarded as a standard, often detailed mineralogical analyses would not be required prior to experiments (Raveia et al., 2008). Other standard sand includes CEN (Committee for European Norms), Toyoura sand is Japanese sand extensively studied by several investigators (Shiratori et al., 2007; Chiaro et al., 2013). 
Quartzanium is the Indian standard sand as per IS-650: 1991 of the Bureau of Indian Standards (BIS), used by various cement plants, research laboratories, and civil engineering institutions to ensure the quality of Cement (BIS, 1991). Other agencies that provide standards of blocks include Canadian Standards Association, Masonry Association of Australia, South Africa Bureau of Standards, and Standards Association of New Zealand. In Ghana, Regional Metropolitan Assemblies enforce codes for testing strengths of buildings. The codes are provided by the Ghana Institution of Engineers, Ghana Standards Authority and Ghana Highway Authority.

To ensure the quality and safety of construction, it is crucial that standards and legislation are in place, that define the minimum geotechnical properties of sand for various purposes (Tetsopgang et al., 2020). While sand is critical for economic growth, sand extraction is also responsible for the disappearance of landforms and soil degradation (Kundu \& Ghose, 1997, 1998; Sklenicka et al., 2004) with the potential to impact water quality in rivers and streams and agricultural practices. To check the suitability of soil to be used as a foundation or as construction materials, its properties are required to be assessed (Laskar \& Pal, 2012). In the study areas were sand is mined, no engineering tests are performed on these sands that are used for construction and other engineering works.

This research seeks to determine the suitability of the natural sands in the study areas for construction using geotechnical and geochemical techniques whilst the environmental implications because of the exploitation of sand are also addressed.

\section{Study Area}

\subsection{Location}

The study area includes four (4) town namely Banso, Pumponi, Fretsi and Tumentu which is in the Ahanta west district, southwestern part of Ghana (Figure 1 ). The district lies between latitudes $4^{\circ} 45^{\prime} 00^{\prime \prime} \mathrm{N}$ and $4^{\circ} 57^{\prime} 00^{\prime \prime} \mathrm{N}$, and longitudes $1^{\circ} 45^{\prime} 00^{\prime \prime} \mathrm{W}$ and $2^{\circ} 13^{\prime} 00^{\prime \prime} \mathrm{W}$. The study Areas generally have a flat land with a few isolated hills at Butre and Banso with height ranging between 20 to 40 meters above sea level between Cape Three Point and Princess Town (Ewur et al., 2010). The areas fall largely within the High Rain Forest Vegetation Zone, capturing several hectares of rubber plantation.

The coastline has features such as capes and bays especially at Cape Three Points. The largest river in the district is Butre, and other seasonal rivers such as Apesuro, Whin, Suoni, Nyila, Nyame and Yani. The drainage pattern is basically dendritic and impacts positively on the soil fertility for agriculture (Mahama \& Annan, 2014). The district falls within the Southwestern equatorial climatic zone of Ghana. The highest mean temperature is $34^{\circ} \mathrm{C}$ that is recorded between March and April, while the lowest mean temperature of $20^{\circ} \mathrm{C}$ is experienced in August. Relative humidity is very high averaging between $75 \%$ to $85 \%$ in the rainy season and $70 \%$ to $80 \%$ in the dry season. The district is in the wettest region of Ghana and experiences a double maxima rainfall of over $1700 \mathrm{~mm}$. The 

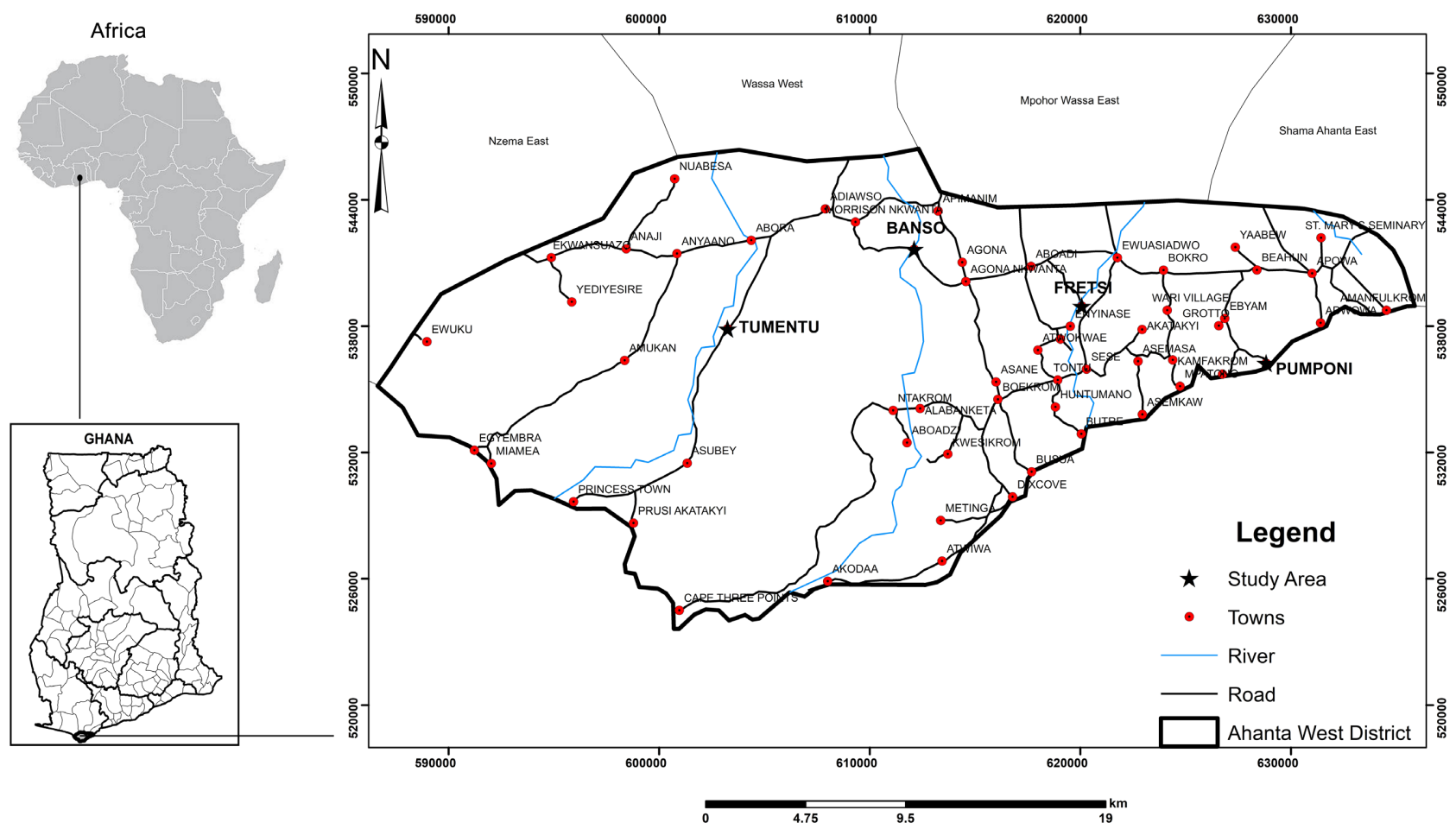

Figure 1. Location of study areas.

rainy season is between the months of April and September, with the greatest volume recorded between April and July.

\subsection{Geology}

The Geology of Ahanta West is associated with rocks belonging to the Birimian Supergroup and Sekondian group (Figure 2). The Birimian is made of Metasedimentary and Metavolcanic rocks. The Metasedimentary rocks are predominantly of pelitic origin consisting of mud and silts with beds of coarser sediments. The series is now represented by great thickness of isoclinally folded, steeply dipping, alternating slates, phyllites, greywacke and argillaceous beds with some tuffs and lavas (Kesse, 1985).

The Meta-volcanic Birimian unconformably overlies the Meta-sedimentary Birimian and takes up $20 \%$ of the area occupied by the whole Birimian. The series consists of great thicknesses of basaltic and andesitic lavas, beds of agglomerates, tuff and tuffaceous sediments (Kesse, 1985). The Tarkwaian is thought to rest unconformably on the Birimian. Intruded into the Birimian are large masses of granitoids of uncertain ages but probably post-Birimian or pre-Tarkwaian age. These granitoids are related to the later stages of the Eburnean orogeny at or after the end of the Birimian deposition (Kesse, 1985). The Sekondian Series consists mainly of sandstones, shale with conglomerates, pebble beds, grits and mudstones resting with a major unconformity on a complex of granites, gneisses and schists (Asiedu et al., 2000).

Locally, the study area is dominated with the volcanic-belt granitoids made up 


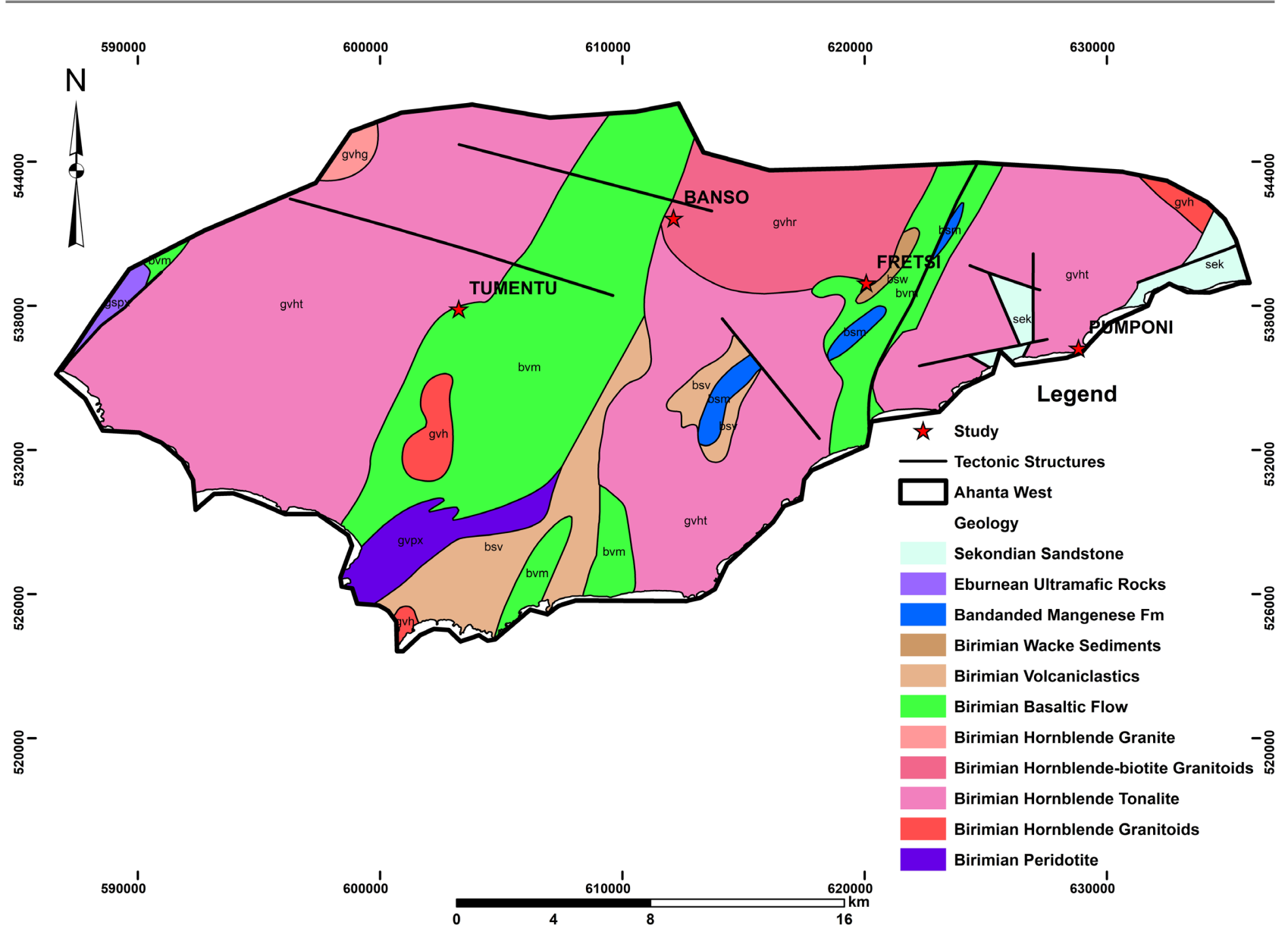

Figure 2. Geology of the Ahanta west area.

of Dixcove-type granite complexes. This complex forms non-foliated discordant and semi-discordant bodies in the enclosing country rocks, which are generally Birimian meta-volcanics. The Dixcove granite is intruded along deep-seated faults in three distinct phases, which follow one another from basic to acid; gabbro-diorite-granodiorite (Kesse, 1985). Tumentu is also characterized by Birimian volcanic rocks which are synvolcanic intrusive rocks and are dominated by horneblende-biotite tonalite. Fretsi falls within both the Birimian volcanics and sedimentary group. Pumponi is characterized by synvolcanic intrusive rocks hornblende-biotite tonalite and Sekondian sandstone.

\section{Materials and Methods}

Geotechnical test works were conducted on the sand samples from the study areas at the University of Mines and Technology (UMaT) Geotechnical Laboratory in Tarkwa, Ghana. All the soil physical property tests were conducted according to the British Standard (BS) for testing soils. The following tests were done, Moisture content (BS, 1990: Part 2), Specific gravity (BS, 1990: Part 2), Silt test (BS, 1990: Part 2) and Particle size distribution (BS, 1990: Part 2). The geochemical analysis was done at the Environmental and Monitoring Laboratory at UMaT, Tarkwa. The results of the geotechnical test were compared 
with the British Standards (BS) and American Standards for Testing Materials (ASTM) whilst the geochemical test was compared with the standard Ottawa sand.

\subsection{Sampling}

Four (4) towns Agona Banso, Fretsi, Pompuni and Tumentu where sand winning activities occur in the Ahanta West District were sampled (Figure 3). The soil samples were collected using shovel and kept in labelled sample bags. Initially, five samples were collected from each sample point, these samples were latter mixed to make a composite sample. Five sand samples were taken from five different sample locations. Two stream samples were taken, one from the Butre River at Fretsi because of alluvial mining activities. The other stream sample was taken at Tumentu from the Yani River also from alluvial mining activities. The 3 remaining samples were inland samples from sand winning site at Pompuni, Agona Banso and Fretsi. The overburden soils had been taken off because of the sand winning activities in the area. The burrow pits were about 50 $100 \mathrm{~cm}$ deep.

\subsection{Laboratory Test}

The physical properties of soils are usually determined by carrying out tests on soil samples in the laboratory (Head, 1992). The following laboratory tests were conducted at the University of Mines and Technology Environmental and Monitoring Laboratory in Tarkwa for all the sand samples collected from the study areas;

- Particle Size Analysis

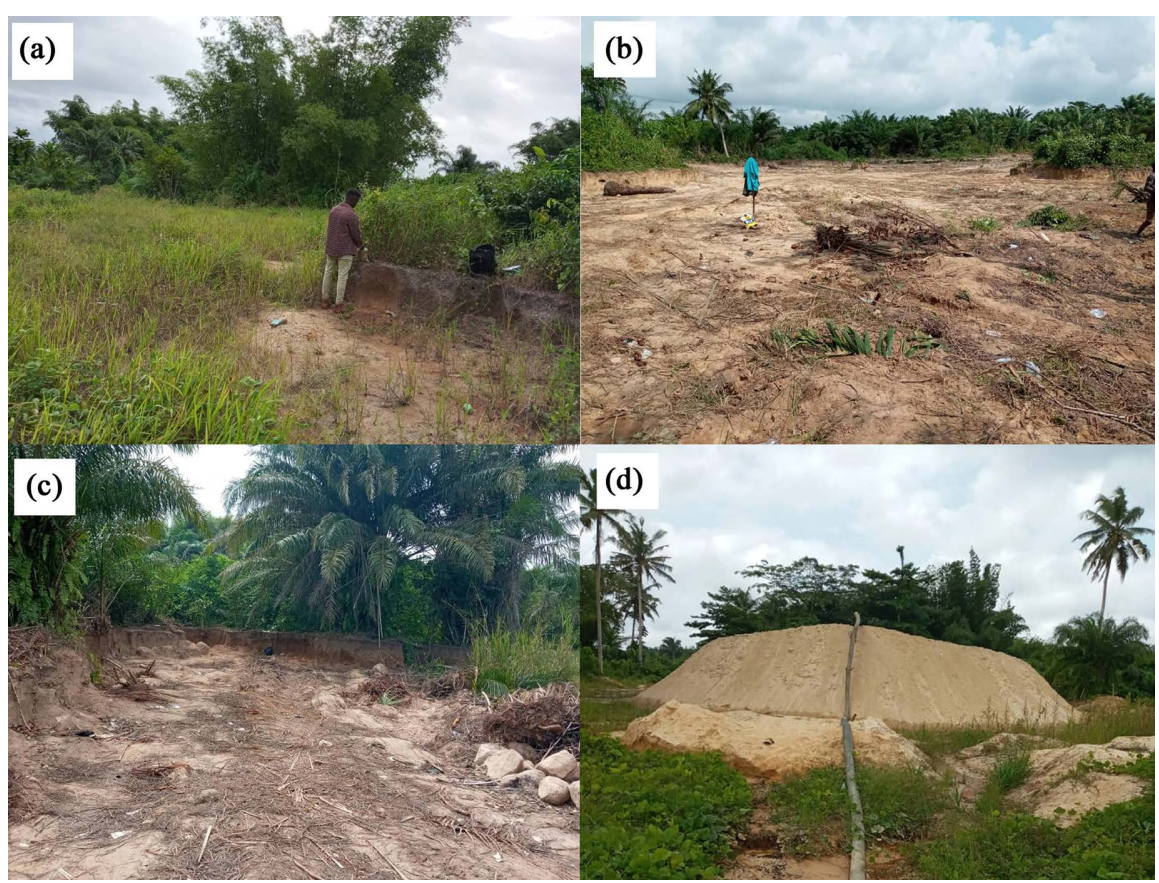

Figure 3. Sand wining sites (a) Agona Banso; (b) Fretsi; (c) Pompuni; (d) Tumentu. 
- Moisture Content Test;

- Silt Content Test;

- Specific Gravity;

- Permeability Test;

- Chemical Test.

\subsubsection{Particle Size Analysis (BS, 1990: Part 2)}

To determine the particle size distribution, $500 \mathrm{~g}$ of each sample was weighed using the balance. The sieves were arranged hierarchically, thus in ascending order with the 63 microns sieve being at the base. Beneath the last sieve is a metallic base (pan). The weighed sample was placed into the top sieve and the whole stuck of sieves were mounted on a shaker for about 3 - 5 minutes with a covered lid. After the sieving, the materials retained on each sieve were examined to ensure consistencies in the particle classes. The weight of the sample retained on each sieve was determined and the cumulative percentages of the sub-sample weight passing each sieve were calculated. It was ensured that agglomerated particles that are not naturally consolidated were broken down and further sieved. Plot percentages passing each sieve size as ordinate were against the particle size on the abscissa, which is drawn to a log scale using Microsoft Excel. The points were linked with a smooth curve or a series of straight line, the percentages of particles passing respective sieve sizes were calculated using Equations (1) to (3).

$$
\begin{aligned}
& \text { Percentage retained }(\%)=(\text { mass retained } / \text { total sample used }) \times 100 \% \\
& \text { Percentage passing }(\%)=100 \%-\text { Percentage retained }(\%) \\
& \text { Cumulative percentage retained on any sieve } \\
& =\text { sum of } \% \text { retained on all coarse sieve }
\end{aligned}
$$

To determine the uniformity co-efficient and coefficient of gradation, equations 4 and 5 were used. Both $C_{U}$ and $C_{C}$ will be unity for a single-sized soil, while $C_{U}<3$ indicates uniform grading and $C_{U}>5$ a well graded soil. Most well graded soils will have grading curves that are mainly flat or slightly concave, giving values of $C_{C}$ between 0.5 and 2.0 (Arora, 1997).

$$
\begin{gathered}
C_{U}=D_{60} / D_{10} \\
C_{C}=\left(D_{30}\right)^{2} /\left(D_{60} / D_{10}\right)
\end{gathered}
$$

where;

$C_{U}=$ Uniformity Co-efficient;

$C_{C}=$ Co-efficient of Gradation;

$D_{10}=$ particle size $(\mathrm{mm})$ passing $90 \%$ of the sieve apertures;

$D_{30}=$ particle size $(\mathrm{mm})$ passing $70 \%$ of the sieve apertures;

$D_{60}=$ particle size $(\mathrm{mm})$ passing $40 \%$ of the sieve apertures.

The Fineness Modulus (FM) can be obtained by adding cumulative percentage of aggregates retained on each sieve and dividing the sum by 100, the FM gives standard for the use of sand in different concrete compositions (Tetsopgang et al., 
2020).

\subsubsection{Determination of Moisture Content (BS, 1990: Part 2)}

To determine the moisture content, two clean containers for each sample are taken and the mass in grams is recorded together with container number. The sample of wet soil is placed in the container and weighed in grams. The container with the wet samples is placed in the oven and the sample is then dried in a thermostatically controlled drying oven which is maintained at a temperature of $105^{\circ} \mathrm{C} \pm 5^{\circ} \mathrm{C}$. The sample is allowed in the oven for 2 to 4 hours, afterwards, the containers are removed from the oven and the samples allowed to cool. After cooling the container plus dry soil are weighed in grams and the coisture Content is calculated using Equation (6).

$$
\text { Moisture Content }=\frac{\text { Mass of sample }- \text { Mass of dry Sample }}{\text { Mass of dry Sample }} \times 100 \%
$$

\subsubsection{Silt Test (BS 812)}

To determine the silt content, the sit test was done. Initially, two measuring cylinders were filled with distilled water to the $500 \mathrm{ml}$ mark and $50 \mathrm{~g}$ of salt was added to the water in the cylinder and carefully shaken to dissolve the salt. The salt was added to aid in the settlement time of the silt. More than half of the water is poured into a clean bowl and the measuring cylinder filled with sand material between $150-200 \mathrm{~g}$. The cylinder is topped up with water from the bowl to reach the $500 \mathrm{ml}$ after which the cylinder with the sand material is allowed to stand for 24 hours for the silt to settle. Afterwards, the height of Sand sample $(\mathrm{ml})$ and height of Silt layer $(\mathrm{ml})$ is recorded, the silt content of the sand is calculated using Equation (7).

Silt Content $=($ Height of Siltlayer $(\mathrm{ml})) /($ Height of Sand Sample $(\mathrm{ml})) \times 100$

\subsubsection{Specific Gravity (ASTM C 128)}

To determine the specific gravity, clean and dry density bottles were first weighed, and its mass recorded as $M_{1} .12 \mathrm{~g}$ each sample, which passed through the $1.18 \mathrm{~mm}$ sieve size, was placed in the density bottle and after weighing, the mass recorded as $M_{2}$. Water was added to the soil in the density bottle to remove entrapped air, the sample was soaked for 15 minutes after which the mass was taken as $M_{3}$. The density bottle was filled with water, the exterior surface of the density bottle was dried and the mass was determined and recorded as $M_{4}$. The specific gravity is calculated using Equation (8).

$$
\text { Specific gravity }=\frac{m_{2}-m_{1}}{\left(m_{4}-m_{1}\right)-\left(m_{3}-m_{2}\right)}
$$

\subsubsection{Permeability (BS, 1990: Part 5)}

To determine the permeability, $1000 \mathrm{~g}$ of dry sample passing the $2 \mathrm{~mm}$ sieve size was used to perform the test. The upper chamber of the permeameter was unscrewed from the cap chamber by loosening the three knurled cap. The scooper 
was used to fetch a proportion of the sample and was placed in the glass chamber. The specimen in the glass chamber was then compacted at 25 blows to the desired density. Enough sample was placed in the chambers and compacted in successive layers until the soil was within $2 \mathrm{~cm}$ of the top of the chamber. The rubber gasket was placed between the chamber sections whilst the chamber cap and the sealing gasket were tightly screwed together to avoid upward movement of the sample. The length of the sample within the chamber was measured. The constant head funnel, rod and the meter stick were assembled. The flexible tube from the tail of the funnel to the bottom outlet were connected and the permeameter valves were then opened. A measuring cylinder was placed at the end to collect the drained water. The bottom outlet valve was opened, and the constant head was raised to a convenient height to attain a steady flow. Adequate time was then allowed for the flow pattern to stabilize. After equilibrium flow was established, the time taken for specific discharge of water in the measuring cylinder was recorded. The procedure was repeated three times to obtain the average time of discharge. The height of the fluid in the column at equilibrium was recorded and the hydraulic conductivity was calculated using Equation (9).

$$
\begin{aligned}
& K=q / A i \\
& K=Q L / A H t(\mathrm{~cm} / \mathrm{s}) \\
& i=\left(h_{2}-h_{1}\right) / L
\end{aligned}
$$

where;

$$
\begin{aligned}
& Q=\text { quantity of water collected in time } t / \mathrm{s} ; \\
& A=\text { cross sectional area of the sample }\left(\mathrm{cm}^{2}\right) ; \\
& H=\text { difference in the manometer levels }(\mathrm{cm}) ; \\
& L=\text { distance between the manometer tapping points }(\mathrm{cm}) .
\end{aligned}
$$

\subsubsection{Chemical Analysis}

The photometer (Hydro Test HT 1000) was used to determine silica, sulphate and chloride concentrations in the sand samples. It is a compact and handheld photometer for testing water quality across over 40 key parameters. It offers a quick and low-cost lightweight colorimetric solution using simple single dose tablet reagents. To use the photometer method, two grams of each of the samples was weighed into a boiling tube and digested using a digestion mixture containing concentrated hydrochloric acid and trioxonitrate (v) acid. The samples were heated for two hours at $120^{\circ} \mathrm{C}$, it was then cooled and filtered. The $\mathrm{X}$-ray fluorescence (XRF) was used to determine the major oxides $\left(\mathrm{Na}_{2} \mathrm{O}, \mathrm{MgO}\right.$, $\mathrm{Al}_{2} \mathrm{O}_{3}, \mathrm{~K}_{2} \mathrm{O}, \mathrm{CaO}, \mathrm{MnO}$ and $\mathrm{Fe}_{2} \mathrm{O}_{3}$ ) of the natural sands. The samples were grinded to size of 75 microns and passed through the XRF machine to obtain the major oxides composition.

\section{Results and Discussions}

\subsection{Description of Sand Grains}

The natural sand grains are predominantly made of quartz and feldspar minerals 
(Table 1 and Figure 4). The samples from the streams are poorly sorted whilst those from inland are moderately to well sorted. Sand grains from the streams are subangular to subrounded coarse particles whilst those inlands are subrounded with fine particles. The colour of the sand from the various locations are pale yellow, pale brown, brown and yellow. From the scale in Figure 4 the particle sizes range between $0-1 \mathrm{~mm}$.

\subsection{Soil Profile}

The sand and gravel deposits in southern Ghana are derived from three main geologic sources. They may occur us residual deposits (in quartzite, sandstone, granite and felsic gneiss terrain), as alluvial deposits (within the precincts of river/stream valleys) or as beach deposits. Most sand and gravel deposits are up

Table 1. Description of sand grains.

\begin{tabular}{|c|c|c|c|}
\hline Town & GPS Location & Description & Mineral \\
\hline Pompuni & $\begin{array}{l}1^{\circ} 51^{\prime} 12^{\prime \prime} \mathrm{W} \\
4^{\circ} 51^{\prime} 0 " \mathrm{~N}\end{array}$ & $\begin{array}{l}\text { Moderately Sorted, Sub rounded, } 0.5 \mathrm{~mm} \text {, } \\
\text { Pale yellow }\end{array}$ & Quartz, Feldspar \\
\hline Fretsi & $\begin{array}{l}1^{\circ} 55^{\prime} 35.79^{\prime \prime} \mathrm{W} \\
4^{\circ} 53^{\prime} 45.45^{\prime \prime} \mathrm{N}\end{array}$ & $\begin{array}{l}\text { moderately sorted, Sub rounded, fine } \\
\text { particles }(0.3 \mathrm{~mm}) \text {, pale yellow }\end{array}$ & $\begin{array}{l}\text { Quartz, Feldspar, Others } \\
\text { (dull black minerals) }\end{array}$ \\
\hline Fretsi Stream & $\begin{array}{c}1^{\circ} 55^{\prime} 44.88^{\prime \prime} \mathrm{W} \\
4^{\circ} 53^{\prime} 53^{\prime \prime} \mathrm{N}\end{array}$ & $\begin{array}{l}\text { Poorly sorted, Sub angular to sub rounded, } \\
\text { coarse particles }(1 \mathrm{~mm}) \text { pale brown }\end{array}$ & Quartz, Feldspar \\
\hline $\begin{array}{l}\text { Tumentu } \\
\text { Stream }\end{array}$ & $\begin{array}{c}2^{\circ} 54^{\prime} 11.42^{\prime \prime} \mathrm{W} \\
4^{\circ} 52^{\prime} 5.32^{\prime \prime} \mathrm{N}\end{array}$ & $\begin{array}{l}\text { Poorly sorted, sub rounded to sub angular, } \\
\text { coarse particles }(0.8 \mathrm{~mm}) \text {, yellow }\end{array}$ & Quartz, Feldspar \\
\hline Agona Banso & $\begin{array}{l}1^{\circ} 58^{\prime \prime} \mathrm{W} \\
4^{\circ} 45^{\prime \prime} \mathrm{N}\end{array}$ & Well sorted, sub rounded, $0.5 \mathrm{~mm}$, brown & Quartz, Feldspar \\
\hline
\end{tabular}
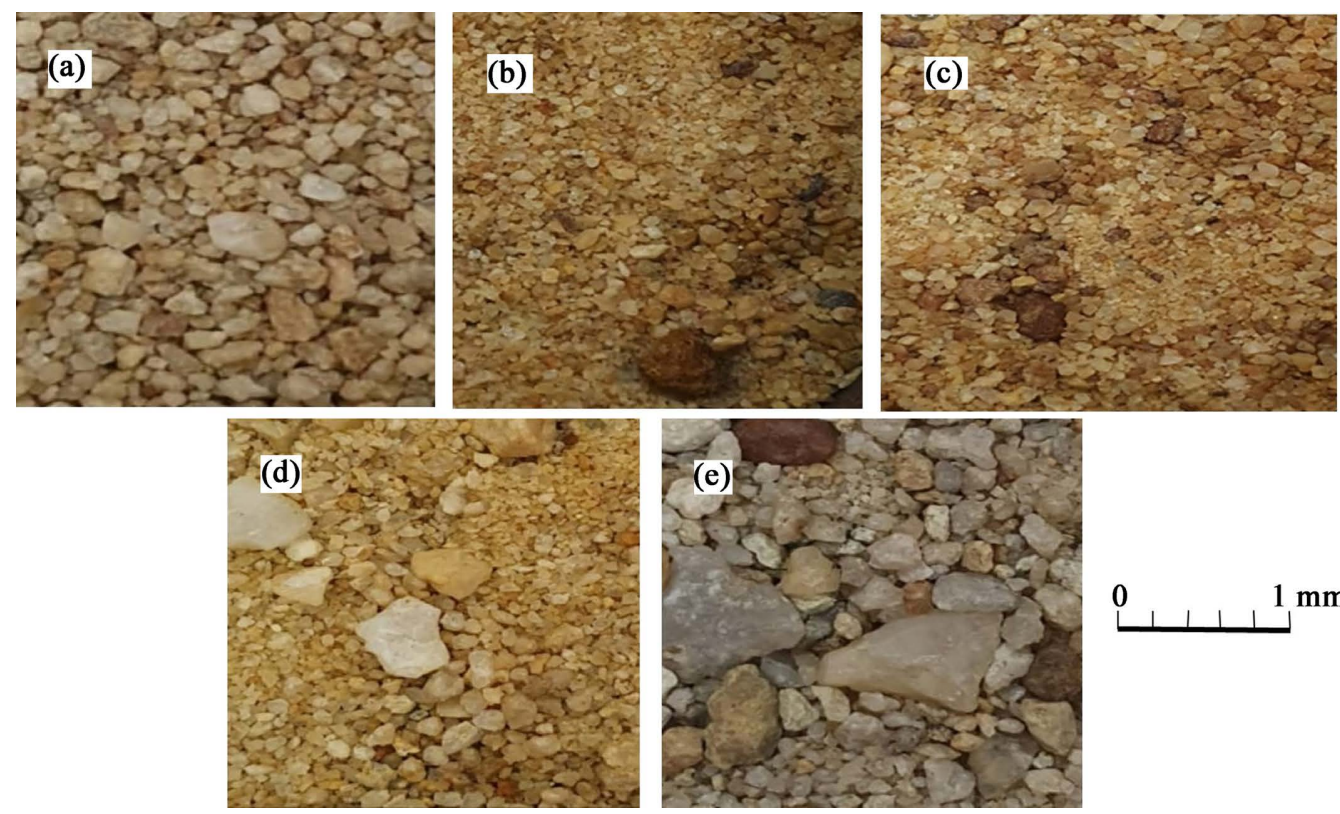

$1 \mathrm{~mm}$

Figure 4. Hand specimen of sand samples (a) Agona Banso; (b) Fretsi; (c) Pompuni; (d) Tumentu stream; (e) Fretsi stream. 

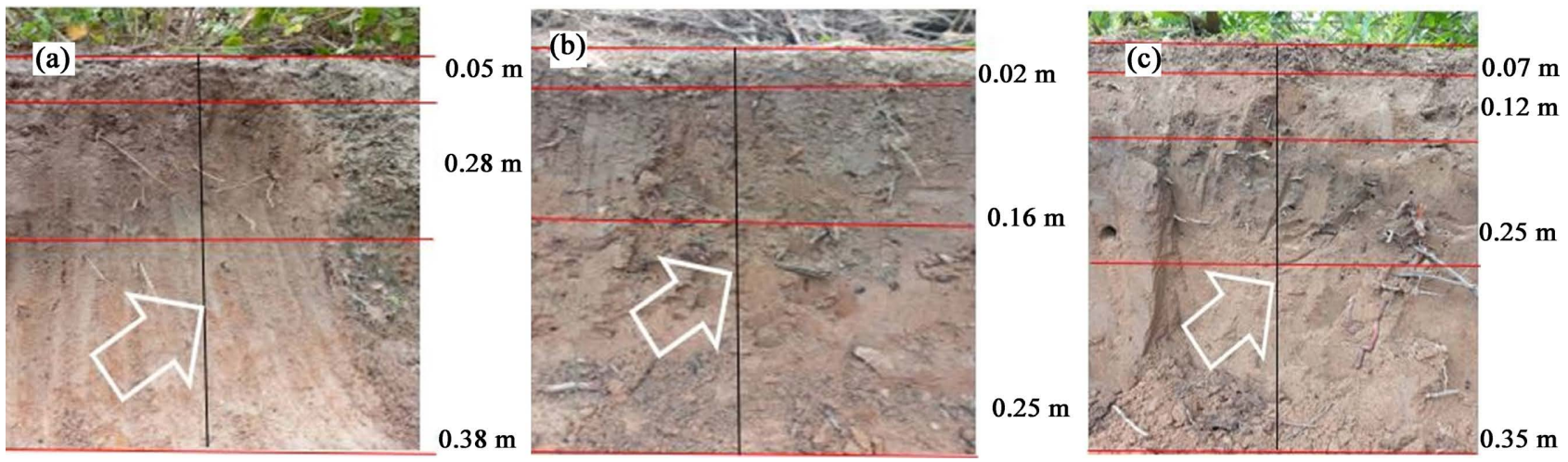

Figure 5. Soil profile (a) Agona Banso, (b) Fretsi; (c) Pompuni. 
Table 2. Results of particle size analysis.

\begin{tabular}{|c|c|c|c|c|c|c|c|c|c|}
\hline Town & Sieve Size & $10.00 \mathrm{~mm}$ & $5.00 \mathrm{~mm}$ & $2.36 \mathrm{~mm}$ & $1.18 \mathrm{~mm}$ & $600 \mu \mathrm{m}$ & $300 \mu \mathrm{m}$ & $150 \mu \mathrm{m}$ & pan \\
\hline \multirow[t]{5}{*}{ Fretsi } & Weight Retained (g) & 0.00 & 1.50 & 19.25 & 46.25 & 111.75 & 127.00 & 98.50 & 94.50 \\
\hline & Retained (\%) & 0 & 0.3 & 3.86 & 9.27 & 22.41 & 25.46 & 19.75 & 18.95 \\
\hline & Passing (\%) & 100 & 99.7 & 95.84 & 86.57 & 64.16 & 38.7 & 18.95 & 0 \\
\hline & Lower Limit & 100 & 89 & 60 & 30 & 15 & 5 & 0 & \\
\hline & Upper Limit & 100 & 100 & 100 & 100 & 100 & 70 & 15 & \\
\hline \multirow[t]{5}{*}{ Pompuni } & Weight Retained (g) & 0 & 5.5 & 61.5 & 197.75 & 122.75 & 66.5 & 28 & 16.25 \\
\hline & Retained (\%) & 0 & 1.1 & 12.34 & 39.69 & 24.64 & 13.35 & 5.62 & 3.26 \\
\hline & Passing (\%) & 100 & 98.9 & 86.56 & 46.87 & 22.23 & 8.88 & 3.26 & 0 \\
\hline & Lower Limit & 100 & 89 & 60 & 30 & 15 & 5 & 0 & \\
\hline & Upper Limit & 100 & 100 & 100 & 100 & 100 & 70 & 15 & \\
\hline \multirow[t]{5}{*}{ Fretsi Stream } & Weight Retained (g) & 0 & 13.7 & 75.75 & 124.75 & 108 & 94.5 & 64.25 & 17.75 \\
\hline & Retained (\%) & 0 & 2.75 & 15.19 & 25.02 & 21.66 & 18.95 & 12.88 & 3.56 \\
\hline & Passing (\%) & 100 & 97.25 & 82.06 & 57.04 & 35.38 & 16.43 & 3.56 & 0 \\
\hline & Lower Limit & 100 & 89 & 60 & 30 & 15 & 5 & 0 & \\
\hline & Upper Limit & 100 & 100 & 100 & 100 & 100 & 70 & 15 & \\
\hline \multirow[t]{5}{*}{ Tumentu Stream } & Weight Retained (g) & 0 & 7 & 16.25 & 61 & 133 & 180.75 & 82.75 & 18.75 \\
\hline & Retained (\%) & 0 & 1.4 & 3.25 & 12.21 & 26.63 & 36.19 & 16.57 & 3.75 \\
\hline & Passing (\%) & 100 & 98.6 & 95.35 & 83.14 & 56.51 & 20.32 & 3.75 & 0 \\
\hline & Lower Limit & 100 & 89 & 60 & 30 & 15 & 5 & 0 & \\
\hline & Upper Limit & 100 & 100 & 100 & 100 & 100 & 70 & 15 & \\
\hline \multirow[t]{5}{*}{ Agona Banso } & Weight Retained (g) & 0 & 9.75 & 32.75 & 94 & 125.75 & 119.5 & 57 & 59.75 \\
\hline & Retained (\%) & 0 & 1.96 & 6.57 & 18.86 & 25.23 & 23.97 & 11.42 & 11.99 \\
\hline & Passing (\%) & 100 & 98.04 & 91.47 & 72.61 & 47.38 & 23.41 & 11.99 & 0 \\
\hline & Lower Limit & 100 & 89 & 60 & 30 & 15 & 5 & 0 & \\
\hline & Upper Limit & 100 & 100 & 100 & 100 & 100 & 70 & 15 & \\
\hline
\end{tabular}

Table 3. Results of uniformity co-efficient, co-efficient of gradation and fineness modulus.

\begin{tabular}{cccc}
\hline Town & $C_{U}=D_{60} / D_{10}$ & $C_{C}=\left(D_{30}\right)^{2} /\left(D_{10} \times D_{60}\right)$ & FM \\
\hline Fretsi & 0 & 0 & 1.95 \\
Pompuni & 5.00 & 1.42 & 3.33 \\
Fretsi Stream & 3.4 & 1.07 & 3.08 \\
Tumentu Stream & 3.4 & 1.06 & 2.42 \\
Agona Banso & 5.00 & 0.89 & 2.55 \\
\hline
\end{tabular}


accurately meet the water requirement of the mix design. If the water content of the concrete mixture is not kept constant, the water-cement ratio will vary from batch to batch causing other properties, such as the compressive strength and workability to vary from batch to batch. Fine aggregate will have moisture content of about $3 \%$ to $8 \%$ (ASTM C 70).

The results of average moisture content and specific gravity of sand from the study areas are presented in Table 4 . The results show that sand samples from Fretsi sand winning site did not meet the moisture content standard of $3 \%$ to $8 \%$. The rest of the sand samples from Pumponi, Fretsi stream, Tumentu stream and Agona Banso met the moisture content requirement.

\subsection{Specific Gravity}

Specific gravity is the ratio of the mass of soil solids to the mass of an equal volume of water. It is an important index property of soils that is closely linked with mineralogy or chemical composition and reflects the history of weathering. Specific gravity is used in computations of mixture proportioning and control, such as the volume occupied by the aggregates in the absolute volume method of mix design (mix design calculations). It is relatively important as far as the qualitative behaviour of the soil is concerned. It gives an idea about suitability of the soil as a construction material; higher value of specific gravity gives more strength for roads and foundations. The average specific gravity of the sand samples is summarized in Table 4. High specific gravity generally indicates high quality aggregate whilst porous, weak or absorptive aggregates have low specific gravities. Thus, the Fretsi sand from the sand winning site has higher strength, followed by the Tumentu stream sample whilst Pomponi and Fretsi stream sample have the same average specific gravity. Agona Banso sand sample has the lowest specific gravity and hence lower strength. All the Average specific gravity of the sand samples is within the range 2.4 and 2.9 (ASTM, 2001: C128) for most natural aggregates.

\subsection{Silt Content}

The results of the silt content of the samples from the various towns are presented in Table 5. British Standard 812 permits silt contents to be within the range of $3 \%$ to $8 \%$ which is suitable for construction purposes. The results indicate that

Table 4. Results of average moisture content and specific gravity.

\begin{tabular}{ccc}
\hline Town & Average Moisture Content (\%) & Average Specific Gravity \\
\hline Pompuni & 7.96 & 2.65 \\
Fretsi Stream & 7.22 & 2.65 \\
Tumentu Stream & 1.39 & 2.67 \\
Fresti & 11.35 & 2.73 \\
Agona Banso & 4.08 & 2.50 \\
\hline
\end{tabular}


sand samples from Agona Banso, Pompuni, Tumentu stream and Fretsi stream have silt contents within the standard range. This will require optimum water and cement content for a reasonable workability. Sand samples from Fretsi have silt content within the range of $17.77 \%-20.00 \%$ and is unsuitable for construction as it increases the amount of water needed to wet the particles in the mix. This result in mix with high slump, high dry shrinkage and consequently weak and nondurable concrete.

\subsection{Permeability}

The results of permeability coefficients of sand and percentage silt are presented in Table 6. The results show that Pompuni, Fretsi Stream and Tumentu stream sand samples have medium permeability due to their subrounded to subangular shape of their particles. These samples did not have a lot of fines, and their silt content was within the standard value (Table 6). Sample from Fretsi sand winning sites had a low permeability due to the fine and less well sorted particles (moderately sorted). Its silt content was high indicating a lot of fines. At Agona Banso, the sand samples were well sorted with fewer fines (silt) hence its medium permeability.

\subsection{Chemical Analysis}

The results of the geochemical composition of the sands from the study areas in Ahanta West are shown in Table 7. The major oxides were Ferric Oxide $\left(\mathrm{Fe}_{2} \mathrm{O}_{3}\right)$, Alumina $\left(\mathrm{Al}_{2} \mathrm{O}_{3}\right)$ and Calcium Oxide $(\mathrm{CaO})$ which represented $97 \%$ of the oxides. $\mathrm{Fe}_{2} \mathrm{O}_{3}$ concentrations ranged from $29,778.9$ ppm to $1908.9 \mathrm{ppm}$ in a decreasing trend from Pompuni to Fretsi. For $\mathrm{Al}_{2} \mathrm{O}_{3}$, concentrations ranged from $11,029.4 \mathrm{ppm}$ to $3891.8 \mathrm{ppm}$ from Pompuni to Tumentu Stream. All samples

Table 5. Results of silt content.

\begin{tabular}{ccccccccccc}
\hline & \multicolumn{2}{c}{ Fretsi } & \multicolumn{3}{c}{ Pompuni } & \multicolumn{2}{c}{ Tumentu Stream } & \multicolumn{3}{c}{ Fretsi Stream Agona Banso } \\
\cline { 2 - 10 } Town & $\mathbf{1}$ & $\mathbf{2}$ & $\mathbf{1}$ & $\mathbf{2}$ & $\mathbf{1}$ & $\mathbf{2}$ & $\mathbf{1}$ & $\mathbf{2}$ & $\mathbf{1}$ & $\mathbf{2}$ \\
\hline Height of Soil Sample (ml) & 250.00 & 225 & 200.00 & 207.00 & 195.00 & 190.00 & 180.00 & 210.00 & 200.00 & 190.00 \\
Height of Silt Layer (ml) & 50.00 & 40.00 & 15.00 & 15.00 & 15.00 & 11.00 & 10.00 & 10.00 & 10.00 & 10.00 \\
Silt Content (\%) & 20.00 & 17.77 & 7.50 & 7.25 & 7.69 & 5.79 & 5.56 & 4.76 & 5.00 & 5.30 \\
\hline
\end{tabular}

Table 6. Results of permeability coefficients of sand and percentage silt.

\begin{tabular}{cccc}
\hline Town & Permeability $(\mathrm{cm} / \mathrm{sec})$ & Silt (\%) & Qualitative Description \\
\hline Pompuni & 0.01 & 7.38 & Medium \\
Fretsi Stream & 0.05 & 5.16 & Medium \\
Tumentu Stream & 0.03 & 6.74 & Medium \\
Fretsi & 0.000472 & 18.89 & Low \\
Agona Banso & 0.00575 & 8.82 & Medium
\end{tabular}


Table 7. Geochemical composition of sands from the Ahanta west study areas.

\begin{tabular}{ccccccccccc}
\hline Town & $\begin{array}{c}\mathrm{Fe}_{2} \mathrm{O}_{3} \\
(\mathrm{ppm})\end{array}$ & $\begin{array}{c}\mathrm{K}_{2} \mathrm{O} \\
(\mathrm{ppm})\end{array}$ & $\begin{array}{c}\mathrm{MnO} \\
(\mathrm{ppm})\end{array}$ & $\begin{array}{c}\mathrm{CaO} \\
(\mathrm{ppm})\end{array}$ & $\begin{array}{c}\mathrm{Al}_{2} \mathrm{O}_{3} \\
(\mathrm{ppm})\end{array}$ & $\begin{array}{c}\mathrm{Na}_{2} \mathrm{O} \\
(\mathrm{ppm})\end{array}$ & $\begin{array}{c}\mathrm{MgO} \\
(\mathrm{ppm})\end{array}$ & $\begin{array}{c}\text { Sulphate } \\
(\mathrm{mg} / \mathrm{kg})\end{array}$ & $\begin{array}{c}\text { Silica } \\
(\mathrm{mg} / \mathrm{kg})\end{array}$ & $\begin{array}{c}\mathrm{Chloride} \\
(\mathrm{mg} / \mathrm{kg})\end{array}$ \\
\hline Pompuni & $29,778.9$ & 0.0 & 202.7 & 3215.4 & $11,029.4$ & 290.2 & 51.8 & 65.0 & 6.2 & 11.5 \\
Agona Banso & $17,055.1$ & 0.0 & 125.2 & 1402.0 & 7460.6 & 658.2 & 37.9 & 160.0 & 14.9 & $<0.5$ \\
Fretsi Stream & $16,282.0$ & 7115.6 & 205.3 & 5998.4 & 4784.9 & 239.0 & 253.2 & 150.0 & 4.7 & $<0.5$ \\
Tumentu Stream & $14,637.2$ & 0.0 & 136.9 & 2858.6 & 3891.8 & 498.4 & 62.7 & 80.0 & 8.5 & 12.5 \\
$\quad$ Fretsi & 1908.9 & 0.0 & 149.8 & 0.0 & 7460.6 & 150.0 & 48.6 & 50.0 & 11.5 & $<0.5$ \\
Ottawa Standard Sand & 200 & 100 & 100 & 100 & 600 & 100 & 100 & - & 998,000 & - \\
\hline
\end{tabular}

had no $\mathrm{K}_{2} \mathrm{O}$ concentration except for Fretsi Stream with $\mathrm{K}_{2} \mathrm{O}$ concentration of $7115.6 \mathrm{ppm}$. Fretsi sample had no $\mathrm{CaO}$ concentration, but the remaining samples had significant amount. MgO concentrations exceeded the standard values with very low concentrations in Agona Banso, Tumentu, Pompuni and Fretsi samples but high in Fretsi stream. A decreasing trend of concentration was observed for the oxides of $\mathrm{Ca}, \mathrm{Mn}, \mathrm{Na}$, and $\mathrm{Mg}$ in the following order: $\mathrm{CaO}>$ $\mathrm{MnO}>\mathrm{NaO}>\mathrm{MgO}$. Sulphate concentrations were low in comparison with the oxides and ranged from $50.0 \mathrm{mg} / \mathrm{kg}$ to $160.0 \mathrm{mg} / \mathrm{kg}$. The concentration of silica in the samples was low with a range of $4.7 \mathrm{mg} / \mathrm{kg}$ to $11.5 \mathrm{mg} / \mathrm{kg}$. The concentrations of chloride found in Agona Banso, Fretsi Stream and Fretsi were less than $0.5 \mathrm{mg} / \mathrm{kg}$, whilst Pompuni and Tumentu stream had chloride concentrations of $11.5 \mathrm{mg} / \mathrm{kg}$ and $12.5 \mathrm{mg} / \mathrm{kg}$ respectively.

Natural sands release silica and different amounts of aluminium, calcium, potassium, sodium and magnesium and they have different damaging potential. The studied sand might release silica from quartz and quartz polymorph, magnesium from biotite, sodium and potassium from especially feldspars and other minerals. The silica content in the sand is very low for all the samples in comparison with the standard silica in Ottawa sand, which indicates a low raw material quality. In addition, a significant amount of $\mathrm{Al}_{2} \mathrm{O}_{3}$ is observed which is above the standard values in all samples. The presence of $\mathrm{Fe}_{2} \mathrm{O}_{3}$ in the samples gives it a light reddish-brown colour, the $\mathrm{Fe}_{2} \mathrm{O}_{3}$ content also exceeds the standard values in all samples. Only the sample from Fretsi stream had a significant concentration of $\mathrm{K}_{2} \mathrm{O}$ above standard Ottawa sand with the remaining samples having zero concentrations. Additionally, all samples had $\mathrm{Na}_{2} \mathrm{O}$ and $\mathrm{MnO}$ exceeding the standard values.

Sand or mineral phases present within the sand particles may with time supply significant number of alkalis to the concrete pore solution resulting in Alkali-silica reaction (ASR). It is an internal chemical reaction between the alkaline components in the cement and active silica-silicate based mineral constituents of some aggregates. The reaction results are the formation of a gel that absorbs water, expands, and produces internal stresses which are sometimes sufficient to cause the concrete to crack. These cracks cause a greater loss of concrete 
strength. The reactivity is potentially harmful only when it produces significant expansions.

High content of chloride in sand leads to structural integrity problems. This composition causes corrosion and rusting in the steel rods used in reinforced concrete. BSI (1988a) specifies chlorides to be $0.06 \% \max$ for reinforced and mass concrete $0.01 \% \max$ for prestressed and steam cured structural concrete. High levels of sulphates in sand decrease compressive strength, splitting tensile strength and modulus of elasticity. BSI (1988b) specifies sulphates to be $0.4 \%$ max. The results (Table 7) indicate that all the samples from the study areas had sulphate and chloride concentrations within the standard values.

\section{Environmental Implications of Sand Wining at Ahanta West}

The sand wining activities in the study areas at Ahanta West in Ghana has negative implications on the environment (Figure 6). Inland sand wining could only commence when the overburden is stripped, this leads to the loss of vegetative cover and sometimes trees which will takes decades to replace. The deforestation leads to elimination of certain plant species and sudden departure of animals that feed on the plants. There is destruction of soil structure and profile due to sand removal. Continuous removal of sand causes complete removal of vegetation and destruction of topsoil and subsoil resulting in a reduction in faunal population. There is contamination of sand aquifer water due to formation of ponds as sand winning operators tend to dig on areas with thick sand bed creating water ponds. Water accumulates in ponds combined with biodegradable materials from flora and fauna wastes causing contamination.

Sand winning from riverbeds results in changes in fluvial morphology, deep tunnels on riverbeds and increase in velocity of flowing water resulting in erosion on riverbanks (Figure 6). In some cases, there is depletion of water resources
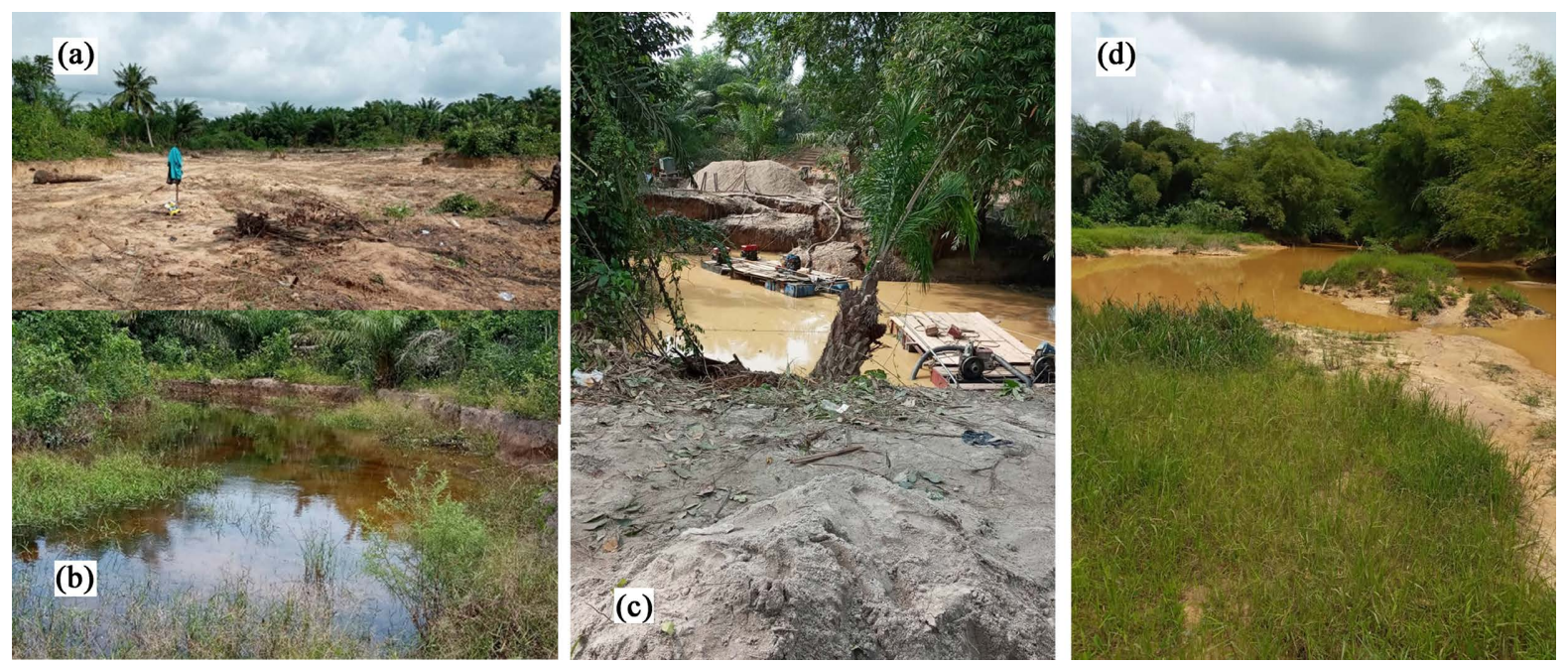

Figure 6. Environmental implications of sand wining at Ahante west (a) Stripped overburden Fretsi, (b) Ponds created Pumponi, (c) Suspended solids in streams Fretsi; (d) Destroyed aquatic habitat Tumentu. 
leading to food shortages and hardships for people. Suspended solids affect the quality of domestic water users downstream which increase treatment costs. In-stream sand mining results in the destruction of aquatic and riparian habitat through large changes in the channel morphology. Impacts include bed degradation, bed coarsening, lowered water tables near the streambed, and channel instability.

\section{Conclusion and Recommendations}

The specific gravity of all the samples was within $2.4-2.9$, which is the standard specified by ASTM C 128 (ASTM, 2001). Sand Samples from Pumponi, Fretsi stream, Agona Banso and Tumentu stream all have moisture content within the standard values of 3\% - 8\% (ASTM, 2013). Apart from Fretsi all the other towns had acceptable silt content (4.76\% - 7.69\%) suitable for construction purposes.

Except for Fretsi with a low coefficient of permeability, all the study areas were medium which makes them suitable for construction purposes. The particle size analysis shows a similar trend where except for Fretsi, all the other samples from the study areas show distributions within the standard grading limit. However, only sand samples from Pumponi and Agona Banso had the required $\mathrm{Cu}$ and $\mathrm{Cc}$ values of being well graded.

Sulphate and chloride concentrations were within standards for all the samples. Silica for all the samples did not meet standards. $\mathrm{Fe}_{2} \mathrm{O}_{3}, \mathrm{Al}_{2} \mathrm{O}_{3}, \mathrm{MnO}$ and $\mathrm{Na}_{2} \mathrm{O}$ did not meet standards for all the samples. All samples had $\mathrm{K}_{2} \mathrm{O}$ concentrations within standards except samples from Fretsi stream. $\mathrm{MgO}$ for all samples was within the standards except samples from Fretsi stream. Only sample from Fretsi had $\mathrm{CaO}$ within the standard, the remaining samples did meet the standard. In conclusion, based on the oxides analysis, all the samples will not be recommended for construction purposes since they failed almost all the oxides concentration tests. The chemical quality of the sand could, however, be improved if it is blended with other quality sands or treated. Selective mining of sand from the site can be adopted to improve the quality of the sand.

There are serious environmental implications for the sand winning activities in the study areas. It is recommended that indiscriminate opening of plots for sand removal should be discouraged by appropriate local authorities. The government of Ghana should evolve a policy compelling the people who engage in sand winning to reinvest and repair the old sites and reclaim the site after completion of the sand winning activity. Sand winning activities in river bodies should be stopped as damage made to aquatic habitats is almost impossible to repair.

\section{Conflicts of Interest}

The authors declare no conflicts of interest regarding the publication of this paper.

\section{References}

Abdullahi, M. (2006). Properties of Some Natural Fine Aggregates in Minna. Nigeria and Environs Civil Engineering Department, Federal University of Technology. 
Ajagbe, W.O., Tijani, M. A., Arohunfegbe, I. S., \& Akinleye M. T. (2017). Assessment of Fine Aggregates from Different Sources in Ibadan and Environs for Concrete Production. Nigerian Journal of Technological Development, 15, 7-13.

Anon (2017). Industrial and Specialty Products. U.S. Silica. https://www.ussilica.com/

Ansah, M. E. (2014). AMA Submits Report on Collapsed Buildings. CitiFM News. https://citifmonline.com/2014/07/ama-submits-report-on-collapsed-buildings-to-police/

Aromolaran, A. K. (2012). Effects of Sand Winning Activities on Land in Agrarian Communities of Ogun State, Nigeria. Continental Journal of Agricultural Science, 6, 41-49.

Arora, K. R. (1997). Soil Mechanics and Foundation Engineering (pp. 1-90). Standard Publishers Distributors.

Asiedu, D. K., Atta-Peters, D., \& Peprah, R. (2000). Depositional Environment of the Takoradi Sandstone formation of the Sekondian Group, Western Ghana, as Revealed by Textural Analysis. Ghana Mining Journal, 6, 53-58.

ASTM (2013). ASTM C70-13. Standard Test Method for Surface Moisture in Fine Aggregate. ASTM International.

ASTM (American Society for Testing and Materials) (2001). C128. Standard Test Method for Density, Relative Density (Specific Gravity), and Absorption of Fine Aggregate. American Society for Testing and Materials.

ASTM (American Society for Testing and Materials) (2003). C125. Standard Terminology Relating to Concrete and Concrete Aggregates. American Society for Testing and Materials.

Baba, S. (2017). Implications of Sand Mining on the Environment and Livelihoods in Brong Ahafo Region. Unpublished Doctoral Thesis Submitted to the Department of Geography and Rural Development, Kwame Nkrumah University of Science and Technology.

BIS Indian (1991). IS Standards Codes IS 650. Specification for Standard sand for Testing of Cement. Bureau of Indian Standards, India.

BS (British Standards) (1990). BS 1377. Methods of Test for Soil for Civil Engineering Purposes. British Standards Institution.

BSI (1988a). BS 812-117: Testing Aggregates. Method for Determination of Water-Soluble Chloride Salts. British Standards Institution.

BSI (1988b). BS 812-118: Testing Aggregates. Method for Determination of Sulphate Content. British Standards Institution.

Chen, B., \& Liu, J. (2004). Effect of Aggregate on the Fracture Behaviour of High-Performance Concrete. Construction and Building Materials, 18, 585-590. https://doi.org/10.1016/j.conbuildmat.2004.04.013

Chiaro, G., Kiyota, T., \& Koseki, J. (2013). Strain Localization Characteristics of Loose Saturated Toyoura Sand in Undrained Cyclic Torsional Shear Tests with Initial Static Shear. Soils and Foundations, 53, 23-34. https://doi.org/10.1016/j.sandf.2012.07.016

Dreux, G., \& Fiesta, J. (1995). Nouveau guide du béton (7th ed.). Eyrolles. (In French)

Erdoğan, S. T., Forster, A. M., Stutzman, P. E., \& Garboczi, E. J. (2017). Particle-Based Characterization of Ottawa Sand: Shape, Size, Mineralogy, and Elastic Moduli. Cement and Concrete Composites, 83, 36-44.

https://doi.org/10.1016/j.cemconcomp.2017.07.003

Ewur, N. E. T., Adupong, R., Eshun, J. D., Mensah, P. A., Nketia, J., \& Gormey, B. (2010). Report on Characterization of Coastal Communities and Shoreline Environments in the Western Region of Ghana, Integrated Coastal and Fisheries Governance Initiative for the Western Region of Ghana (pp. 147-148). USAID Publishers. 
Gopi, S. (2009). Basic Civil Engineering (348 pp). Pearson Education.

Head, K. H. (1992). Manual of Soil Laboratory Testing (2nd ed., 388 pp). Pentech Press Limited.

Jonah, F. E., Adjei-Boateng, D., Agbo, N. W., Mensah, E. A., \& Edziyie, R. E. (2015). Assessment of Sand and Stone Mining along the Coastline of Cape Coast, Ghana. Annals of GIS, 21, 223-231. https://doi.org/10.1080/19475683.2015.1007894

Kesse, G. O. (1985), The Mineral and Rock Resources of Ghana (610 pp). A. A. Balkema Publishers.

Kundu, N. K., \& Ghose, M. K. (1997). Soil Profile Characteristics in Rajmahal Coalfield Area. Indian Journal of Soil Conservation, 25, 28-32.

Kundu, N. K., \& Ghose, M. K. (1998). Status of Soil Quality in the Subsided Areas caused by Underground Coal Mining. Indian Journal of Environmental Protection, 25, 110-113.

Laskar, A., \& Pal, S. K. (2012). Geotechnical Characteristics of Two Different Soils and Their Mixture and Relationships between Parameters. Electronic Journal of Geotechnical Engineering, 17, 282-283.

Machuki, O.V. (2012). Causes of Collapse of Buildings in Mombasa County. A Case of Mombasa City-Kenya. Department of Extra Mural Studies, University of Nairobi. http://ems.uonbi.ac.ke

Madyise, T. (2013). Case Studies of Environmental Impacts of Sand Mining and Gravel Extraction for Urban Development in Gaborone (444 pp). Unpublished Master's Thesis, University of South Africa.

Mahama, A. M., \& Annan, P. K. (2014). District Analytical Report: Ahanta West District. In Ghana Population Census 2010 (pp. 1-4). Ghana Statistical services.

Mattamana, B. A., Varghese, S., \& Kichu, P. (2013). River Sand Inflow Assessment and Optimal Sand mining policy Development. International Journal of Emerging Technology and Advanced Engineering, 3, 305-317.

Mehta, P. K., \& Monteiro, P. J. M. (2001). Concrete Microstructure, Properties and Materials (4th ed., 239 pp). Mc Graw-Hill Professional.

Mireku-Gyimah, D., \& Tsidzi, K. E. N. (1996). Sand and Gravel Winning and Environmental Sustainability in Southern Ghana. Ghana Mining Journal, 2, 46-52.

Musah, J. A. (2009). Assessment of Sociological and Ecological Impacts of Sand and Gravel Mining: A Case Study of East Gonja District (Ghana) and Gunnarsholt (Iceland) (76 pp). Final Report, Land Restoration Training Programme.

Narh, P. (2016). Sand Winning in Dormaa as an Interlocking of Livelihood Strategies with Environmental Governance Regimes. Environment, Development and Sustainability, 18, 467-480. https://doi.org/10.1007/s10668-015-9657-7

Ojuri, O. O., \& Fijabia, D. O. (2012). Standard Sand for Geotechnical Engineering and Geoenvironmental Research in Nigeria: Igbokoda Sand. Advances in Environmental Research, 1, 305-321. https://doi.org/10.12989/aer.2012.1.4.305

Oloyede, S., Omoogun, C., \& Akinjare, O. (2010). Tackling Causes of Frequent Building Collapse in Nigeria. Journal of Sustainable Development, 3, 127-132. https://doi.org/10.5539/jsd.v3n3p127

Peprah, K. (2013). Sand Winning and Land Degradation: Perspective of Indigenous sand Winners of Wa, Ghana. Journal of Environment and Earth Science, 3, 185-194.

Petrounias, P., Giannakopoulou, P. P., Rogkala, A., Stamatis, P. M., Tsikouras, B., Papoulis, D., Lampropoulou, P., \& Hatzipanagiotou, K. (2018). The Influence of Alteration of Aggregates on the Quality of the Concrete: A Case Study from Serpentinites and 
Andesites from Central Macedonia (North Greece). Geosciences, 8, Article No. 115. https://doi.org/10.3390/geosciences8040115

Petrounias, P., Rogkala, A., Kalpogiannaki, M., Tsikouras, B., \& Hatzipanagiotou, K. (2016). Comparative Study of Physico-Mechanical Properties of Ultrabasic Rocks (Veria-Naousa Ophiolite) and Andesites from Central Macedonia (Greece). Bulletin of the Geological Society of Greece, 50, 1989-1998. https://doi.org/10.12681/bgsg.11945

Rao, G. A., \& Prasad, B. K. R. (2002). Fracture Energy and Softening Behaviour of HighStrength Concrete. Cement and Concrete Research, 32, 247-252. https://doi.org/10.1016/S0008-8846(01)00667-6

Raveia, M. A., Hendrickson, S. B., Fitzgerald, J. T., Krekeler, M. P. S., \& Kearns, L. E. (2008). Investigations of Impurities of the Ottawa Standard Sand. In 2008 Joint Meeting of The Geological Society of America, Soil Science Society of America, American Society of Agronomy, Crop Science Society of America, Gulf Coast Association of Geological Societies with the Gulf Coast Section of SEPM. The Society for Sedimentary Geology.

Shiratori, K., Yamashita, Y., \& Adachi, Y. (2007). Deposition and Subsequent Release of Na-Kaolinite Particles by Adjusting $\mathrm{pH}$ in the Column Packed with Toyoura Sand. Colloids and Surfaces A: Physicochemical and Engineering Aspects, 306, 137-141. https://doi.org/10.1016/j.colsurfa.2007.04.003

Sklenicka, P., Prikryl, L., Svoboda, I. and Lhota, T. (2004). Non-Productive Principles of Landscape Rehabilitation after Long-Term Opencast Mining in North-West Bohemia. Journal-South African Institute of Mining and Metallurgy, 104, 83-88

Tetsopgang, S., Bongsiysi, B. B., Dinayen, L.S., \& Nkenglefac, T. F. D. (2020). Geotechnical Assessment of Sand for Civil Engineering in Western Cameroon. The Extractive Industries and Society, 7, 497-504. https://doi.org/10.1016/j.exis.2019.05.005

Thomas, M. D. A., \& Folliard, K. J. (2007). Concrete Aggregates and the Durability of Concrete. In C. L. Page, \& M. M. Page (Eds.), Durability of Concrete and Cement Composites (pp. 247-281). Woodhead Publishing. https://doi.org/10.1533/9781845693398.247 